\title{
CONTROL OF WEEDS IN IMIDAZOLINONE TOLERANT MAIZE WITH IMAZETHAPYR PLUS IMAZAPYR
}

\author{
T.K JAMES ${ }^{1}$, A. RAHMAN ${ }^{1}$ and J.S. GRAY ${ }^{2}$ \\ ${ }^{1}$ AgResearch, Ruakura Research Centre, PB 3123, Hamilton, New Zealand \\ ${ }^{2}$ BASF New Zealand Ltd, PO Box 407, Auckland 1015, New Zealand \\ Corresponding author: trevor.james@agresearch.co.nz
}

\begin{abstract}
Three trials conducted in Waikato evaluated the use of the proprietary imidazolinone herbicide mixture of imazethapyr plus imazapyr for weed control in imidazolinone tolerant (IT) maize crops. A range of herbicide rates, application times and adjuvants were evaluated. The results show that imazethapyr/imazapyr herbicide mixture was very effective in controlling a variety of both monocotyledonous and dicotyledonous annual weeds. Some perennial weeds present in the trials were also well controlled. Imazethapyr/imazapyr was more effective when applied early post-emergence and Hasten ${ }^{\circledR}$ was the most effective adjuvant for increasing the efficacy of imazethapyr/imazapyr. The IT maize crop and final grain yields were not affected by these herbicides.

Keywords: herbicide tolerant maize, weed control, imidazolinone, imazethapyr, imazapyr, Lightning $®$.
\end{abstract}

\section{INTRODUCTION}

The use of genes conveying herbicide tolerance in crop plants has introduced a new level of management for growers. Often the herbicide to which the crop is tolerant, can effectively control weeds that have been difficult to control in the past. These weeds may have been difficult to control due to the low potency of the herbicides that can be used in the crop or because the weed is closely related to the crop and cannot be controlled selectively.

The genes that convey herbicide tolerance may be introduced into a host plant either by genetic engineering or by traditional breeding. In the former a tolerant gene from another species is usually used to confer tolerance, while in the latter the gene comes from a plant of the same species that has shown unnaturally high tolerance to the herbicide. The tolerance of maize plants to the imidazolinone family of herbicides was achieved by traditional breeding methods using a regenerated plant selected as resistant in tissue cell culture (Botterman \& Leemans 1988; Shaner 1996; Owen 1997).

The imidazolinone herbicides were developed in the late 1970s and 1980s for use in a range of crops including oil palms, rubber trees, sugarcane, forestry, soya beans, cereals, sunflower and lentils. They have a broad spectrum of weed control that includes both monocotyledonous and dicotyledonous species. These chemicals are absorbed by both roots and leaves of plants, thus, weeds can be controlled by both soil and foliar application of these herbicides (Shaner 1991). After translocation to the site of action in the growing point of the plant they inhibit the enzyme acetohydroxyacid synthase (AHAS) and disrupt protein synthesis and cell growth. The mode of action is similar to that of the acetolactate synthase (ALS) inhibiting herbicides (mainly sulfonylureas) and cross resistance in weeds is a possibility (Botterman \& Leemans 1988). Some imidazolinone herbicides have also been shown to be moderately persistent and mobile in New Zealand soils (James et al. 1999; Rahman et al. 1993)

The herbicide Lightning ${ }^{\circledR}$ is a proprietary mix of the imidazolinone herbicides imazethapyr $(525 \mathrm{~g} / \mathrm{kg}$ ) and imazapyr $(175 \mathrm{~g} / \mathrm{kg})$, formulated as a dry granule (DG). This paper reports on field trials evaluating the efficacy of imazethapyr/imazapyr for controlling weeds in imidazolinone tolerant (IT) maize.

New Zealand Plant Protection 54:162-167 (2001) 


\section{MATERIALS AND METHODS}

Three field trials were conducted between 1997 and 1999 at different sites in Waikato. At each site an IT maize (Zea mays, cv. Cobra or Garst 451) was planted using conventional methods. All trials were randomised block designs with individual plots of $10 \mathrm{~m} \times 3 \mathrm{~m}$ containing four crop rows and treatments were replicated four times. All herbicide treatments were applied with a $\mathrm{CO}_{2}$ powered precision sprayer in 213 - 300 litres water/ha at $210 \mathrm{kPa}$.

Trial 1 was sited on a Bruntwood silt loam soil with $61 \%$ sand, $16 \%$ clay, $7.3 \%$ organic carbon and a $\mathrm{pH}$ of 5.6. The crop was planted on 11 November 1997 and the preemergence treatments (Table 1) were applied the following day. At the time of spraying it was overcast, $14^{\circ} \mathrm{C}$, the soil surface was damp and $37 \mathrm{~mm}$ of rain fell within 7 days of treatment. The early post-emergence (EPO) treatments were applied on 28 November 1997 when it was overcast and $18^{\circ} \mathrm{C}$. The maize plants were about $7.5 \mathrm{~cm}$ high with 2 3 leaves and the weeds were mostly willow weed (Polygonum persicaria) with 2 true leaves. On the day after treatment $2 \mathrm{~mm}$ rain fell. The late post-emergence (LPO) treatment was applied on 19 December 1997 when it was sunny and $19^{\circ} \mathrm{C}$. The maize plants were $25-30 \mathrm{~cm}$ high. Two days after this treatment was applied $18 \mathrm{~mm}$ of rain fell.

TABLE 1: Treatments for Trial 1.

\begin{tabular}{|c|c|c|c|c|c|}
\hline $\begin{array}{l}\text { Treatment } \\
\text { no. }\end{array}$ & Pre-emergence & $\begin{array}{l}\text { Rate } \\
\text { (g ai/ha) }\end{array}$ & Post-emergence $^{1}$ & $\begin{array}{l}\text { Rate } \\
\text { (g ai/ha) }\end{array}$ & $\begin{array}{l}\text { Adjuvant } \\
\text { (rate v/v) }\end{array}$ \\
\hline 1 & untreated & & & & \\
\hline 2 & acetochlor & 2520 & & & \\
\hline 3 & $\begin{array}{l}\text { acetochlor }+ \\
\text { pendimethalin }\end{array}$ & $\begin{array}{l}2520+ \\
990\end{array}$ & & & \\
\hline 4 & $\begin{array}{l}\text { imaze/imaza + } \\
\text { pendimethalin }\end{array}$ & $\begin{array}{l}52.5 / 17.5 \\
+990\end{array}$ & & & \\
\hline 5 & & & $\begin{array}{l}\text { imaze/imaza }+ \\
\text { pendimethalin }(\mathrm{EPO})\end{array}$ & $\begin{array}{l}52.5 / 17.5 \\
+990\end{array}$ & Citowett $(0.2 \%)$ \\
\hline 6 & & & imaze/imaza (EPO) & $52.5 / 17.5$ & Citowett $(0.2 \%)$ \\
\hline 7 & & & imaze/imaza (EPO) & $79.8 / 26.2$ & Citowett $(0.2 \%)$ \\
\hline 8 & & & imaze/imaza (EPO) & $158 / 52.5$ & Citowett $(0.2 \%)$ \\
\hline 9 & acetochlor & 2520 & imaze/imaza (EPO) & $52.5 / 17.5$ & Citowett $(0.2 \%)$ \\
\hline 10 & acetochlor & 2520 & imaze/imaza (LPO) & $52.5 / 17.5$ & Citowett $(0.2 \%)$ \\
\hline
\end{tabular}

${ }^{1} \mathrm{EPO}=$ early post-emergence, $\mathrm{LPO}=$ late post-emergence.

Trial 2 was on a Horotiu sandy loam soil with $58 \%$ sand, $15 \%$ clay, $5.8 \%$ organic carbon and a $\mathrm{pH}$ of 5.1. The site was treated with glyphosate prior to cultivation to control perennial weeds and the crop was planted on 5 November 1998. The pre-emergence treatments (Table 2) were applied on 6 November 1998 . At the time it was sunny, $16^{\circ} \mathrm{C}$ and the soil surface was mostly damp with some trash. The post-emergence treatments were applied on 17 November 1998, when the weather was partly cloudy and the temperature about $20^{\circ} \mathrm{C}$. The maize plants were $6-8 \mathrm{~cm}$ high with $4-6$ leaves. At the time of the post-emergence treatment, Treatments 3-10 (which had no pre-emergence treatment) contained weeds up to $5 \mathrm{~cm}$ tall, consisting mostly of spurrey (Spergula arvensis) willow weed, redroot (Amaranthus spp.), smooth witchgrass (Panicum dichotomiflorum), summer grass (Digitaria sanguinalis) and catchfly (Silene gallica).

The site of Trial 3 was on a Bruntwood silt loam soil, similar to that for Trial 1, which had been in continuous maize for several years. It was left undisturbed after harvest and cultivated in spring without the use of a pre-cultivation herbicide. Thus the site contained a dense infestation of creeping buttercup (Ranunculus repens) and regrowth of broadleaved dock (Rumex obtusifolius). The maize was planted on 5 November1998, the pre- 
TABLE 2: Treatments for Trial 2.

\begin{tabular}{|c|c|c|c|c|c|}
\hline $\begin{array}{l}\text { Treatment } \\
\text { no. }\end{array}$ & Pre-emergence & $\begin{array}{l}\text { Rate } \\
\text { (g ai/ha) }\end{array}$ & Post-emergence & $\begin{array}{l}\text { Rate } \\
\text { (g ai/ha) }\end{array}$ & $\begin{array}{l}\text { Adjuvant } \\
\text { (rate v/v) }\end{array}$ \\
\hline 1 & untreated & & & & \\
\hline 2 & $\begin{array}{l}\text { acetochlor + } \\
\text { atrazine }\end{array}$ & $\begin{array}{l}2520+ \\
1500\end{array}$ & & & \\
\hline 3 & & & imaze/imaza & $52.5 / 17.5$ & Hasten $(0.5 \%)$ \\
\hline 4 & & & imaze/imaza & $52.5 / 17.5$ & Hasten $(1.0 \%)$ \\
\hline 5 & & & imaze/imaza & $52.5 / 17.5$ & Weedmaster CT $(0.5 \%)$ \\
\hline 6 & & & imaze/imaza & $52.5 / 17.5$ & Ethokem $(0.5 \%)$ \\
\hline 7 & & & imaze/imaza & $52.5 / 17.5$ & Citowett $(0.2 \%)$ \\
\hline 8 & & & imaze/imaza & $79.8 / 26.2$ & Hasten $(1.0 \%)$ \\
\hline 9 & & & imaze/imaza & $105 / 35.0$ & Hasten $(1.0 \%)$ \\
\hline 10 & & & imaze/imaza & 157.552 .5 & Hasten $(1.0 \%)$ \\
\hline 11 & pendimethalin & 990 & imaze/imaza & $52.5 / 17.5$ & Hasten $(1.0 \%)$ \\
\hline
\end{tabular}

emergence treatments (Table 3) applied on 6 November 1998, the EPO treatments on 20 November 1998 and the LPO treatments on 12 December 1998. Conditions for the EPO application were partly cloudy and $17^{\circ} \mathrm{C}$; maize plants were $8-10 \mathrm{~cm}$ high with $4-5$ leaves, grass and broadleaf weeds had up to 6 true leaves, creeping buttercup had $6-8$ leafed rosettes and docks were regrowing strongly from old roots. Conditions for the LPO application were partly cloudy and $16^{\circ} \mathrm{C}$; maize plants were $40-60 \mathrm{~cm}$ high with $8-10$ leaves, creeping buttercup formed dense mats of large rosettes and broad-leaved dock was $30-50 \mathrm{~cm}$ high with some plants flowering.

TABLE 3: Treatments for Trial 3.

\begin{tabular}{|c|c|c|c|c|c|}
\hline $\begin{array}{l}\text { Treatment } \\
\text { no. }\end{array}$ & Pre-emergence & $\begin{array}{l}\text { Rate } \\
\text { (g ai/ha) }\end{array}$ & Post-emergence $^{1}$ & $\begin{array}{l}\text { Rate } \\
\text { (g ai/ha) }\end{array}$ & $\begin{array}{l}\text { Adjuvant } \\
(\text { rate } v / v)\end{array}$ \\
\hline 1 & untreated & & & & \\
\hline 2 & & & imaze/imaza (EPO) & $79.8 / 26.2$ & Hasten $(1.0 \%)$ \\
\hline 3 & & & imaze/imaza (EPO) & $105 / 35$ & Hasten $(1.0 \%)$ \\
\hline 4 & & & imaze/imaza (EPO) & $158 / 52$ & Hasten $(1.0 \%)$ \\
\hline 5 & $\begin{array}{l}\text { acetochlor + } \\
\text { atrazine }\end{array}$ & $\begin{array}{l}2520+ \\
1500\end{array}$ & dicamba (LPO) & 300 & \\
\hline 6 & acetochlor & 2520 & imaze/imaza (LPO) & $52.5 / 17.5$ & Hasten $(1.0 \%)$ \\
\hline 7 & acetochlor & 2520 & imaze/imaza (LPO) & $79.8 / 26.2$ & Hasten $(1.0 \%)$ \\
\hline 8 & acetochlor & 2520 & imaze/imaza (LPO) & $105 / 35.0$ & Hasten $(1.0 \%)$ \\
\hline 9 & acetochlor & 2520 & imaze/imaza (LPO) & $52.5 / 17.5$ & Weedmaster $(0.5 \%)$ \\
\hline 10 & pendimethalin & 990 & imaze/imaza (LPO) & $79.8 / 26.2$ & Hasten $(1.0 \%)$ \\
\hline
\end{tabular}

${ }^{1} \mathrm{EPO}=$ early post-emergence, $\mathrm{LPO}=$ late post-emergence.

Visual assessments of weed control and crop damage were made on several occasions after application of the treatments. Where applicable, weed dry matter (DM) harvests were taken in January or February by harvesting weeds in duplicate $0.5 \mathrm{~m}^{2}$ quadrats from each plot. The weeds were separated into grasses and broadleaf species before drying and weighing. Grain yields were determined in May (Trials 1 and 2 only) by harvesting 25 cobs from each of the two central rows of each plot. The cobs were air dried for a month then shelled, weighed and the moisture content of the grain measured. Grain yields were adjusted to $14 \%$ moisture content. 
All data were subjected to analysis of variance (ANOVA) to separate the means. Observational data were analysed unmodified but dry matter data were transformed $[\log (x+0.01)]$ before analysis to reduce heterogeneity of variance. The arithmetic means and least significant difference (LSD) are presented for observational data and maize grain yields. For weed dry matter data, significant differences $(\mathrm{P}<0.05)$ were determined on the means of the transformed data and these differences are identified by the letters associated with the means of the raw data presented.

\section{Weed control}

\section{RESULTS}

In Trial 1 all the herbicide treatments resulted in excellent early season weed control. However by late December weeds were beginning to emerge in some of the treatments (Table 4). By the end of January a few fathen plants were present in many of the plots. However, the level of weed control was still very good in most plots with acetochlor plus imazethapyr/imazapyr (both EPO and LPO) and high rate of imazethapyr/imazapyr alone performing the best. For the weed dry matter determination in January the weeds were separated into broadleaf and grass weeds. These results show that broadleaf weeds were well controlled with imazethapyr/imazapyr with only a few late germinating fathen and thorn apple (Datura stramonium) plants escaping (Table 4). Imazethapyr/imazapyr was less effective on the grass weeds with only the high rate giving acceptable control. Thus combinations of imazethapyr/imazapyr and acetochlor covered the weed spectrum and provided excellent weed control.

TABLE 4: Weed control, weed dry matter and grain yield for Trial 1.

\begin{tabular}{|c|c|c|c|c|c|}
\hline \multirow[b]{2}{*}{ Treatment $^{1}$} & \multicolumn{2}{|c|}{ Weed control (\%) } & \multicolumn{2}{|c|}{ Weed DM² $(\mathrm{kg} / \mathrm{ha}) 20.1 .98$} & \multirow{2}{*}{$\begin{array}{c}\text { Grain yield } \\
(\mathrm{t} / \mathrm{ha})\end{array}$} \\
\hline & 30.12 .97 & 30.1 .98 & Broadleaf & Grass & \\
\hline 1 untreated & 0 & 0 & 8063 a & $1050 \mathrm{a}$ & 6.3 \\
\hline 2 Pre & 58 & 50 & $2674 \mathrm{ab}$ & $129 \mathrm{bc}$ & 12.9 \\
\hline 3 Pre & 92 & 75 & $250 \mathrm{~b}$ & $4 \mathrm{e}$ & 12.6 \\
\hline 4 Pre & 97 & 88 & $5 \mathrm{~cd}$ & $31 \mathrm{~cd}$ & 12.6 \\
\hline $5 \mathrm{EPO}$ & 87 & 89 & $0 \mathrm{~d}$ & $246 \mathrm{ab}$ & 12.7 \\
\hline $6 \mathrm{EPO}$ & 71 & 70 & $36 \mathrm{c}$ & 553 a & 12.2 \\
\hline $7 \mathrm{EPO}$ & 86 & 78 & $1 \mathrm{~d}$ & $240 \mathrm{ab}$ & 13.1 \\
\hline 8 EPO & 96 & 96 & $10 \mathrm{~cd}$ & $21 \mathrm{~cd}$ & 13.0 \\
\hline 9 Pre + EPO & 99 & 94 & $0 \mathrm{~d}$ & $11 \mathrm{~cd}$ & 12.3 \\
\hline 10 Pre + LPO & 82 & 94 & $26 \mathrm{c}$ & 5 de & 12.6 \\
\hline LSD $(\mathrm{P}<0.05)$ & 13.3 & 8.8 & & & 1.61 \\
\hline
\end{tabular}

${ }^{1}$ See Table 1 for a detailed description of the treatments.

${ }^{2}$ In each column, data with letters in common are not significantly different $(\mathrm{P}<0.05)$.

Similarly in Trial 2, imazethapyr/imazapyr gave very good control of the broad-leaved weeds present, although the level of control achieved was affected by both the herbicide rate and the adjuvant used. The adjuvant Hasten was superior to the other three adjuvants evaluated, viz. Weedmaster CT Surfactant ${ }^{\circledR}$, Ethokem $®$ and Citowett $₫($ Table 5). Hasten is an esterified seed oil (Canola) and it provided greater efficacy at the $1.0 \% \mathrm{v} / \mathrm{v}$ rate than the $0.5 \% \mathrm{v} / \mathrm{v}$ rate. Weedmaster CT Surfactant and Ethokem are ethoxylated tallow amines while Citowett is an alkylaryl polyglycol ether. Increasing rates of imazethapyr/ imazapyr resulted in better weed control with the high rate of 158/52 g/ha keeping the 
plots weed free for the duration of the crop. As in Trial 1, imazethapyr/imazapyr exhibited less activity on the grass weeds than the broad-leaved weeds. However, all rates and combinations of imazethapyr/imazapyr with Hasten provided better control of the grass weeds than the standard treatment of acetochlor plus atrazine.

TABLE 5: Weed control, weed dry matter and grain yield for Trial 2.

\begin{tabular}{|c|c|c|c|c|c|c|}
\hline \multirow[b]{2}{*}{ Treatment $^{1}$} & \multicolumn{3}{|c|}{ Weed control (\%) } & \multicolumn{2}{|c|}{ Weed DM ${ }^{2}(\mathrm{~kg} / \mathrm{ha})$ 13.1.99 } & \multirow{2}{*}{$\begin{array}{c}\text { Grain yield } \\
(\mathrm{t} / \mathrm{ha})\end{array}$} \\
\hline & 21.12 .98 & 11.1 .99 & 10.5 .99 & Broadleaf & Grass & \\
\hline 1 untreated & 0 & 0 & 0 & 6510 a & 840 ab & 6.7 \\
\hline $2 \operatorname{Pre}(\mathrm{std})$ & 73 & 74 & 71 & $70 \mathrm{c}$ & $1430 \mathrm{a}$ & 10.2 \\
\hline 3 Post & 79 & 83 & 88 & $0 \mathrm{~cd}$ & $260 \mathrm{~b}$ & 11.3 \\
\hline 4 Post & 86 & 89 & 98 & $20 \mathrm{~cd}$ & $120 \mathrm{bc}$ & 10.9 \\
\hline 5 Post & 65 & 76 & 88 & $20 \mathrm{~cd}$ & $630 \mathrm{ab}$ & 11.1 \\
\hline 6 Post & 74 & 83 & 89 & $1200 \mathrm{bc}$ & $830 \mathrm{ab}$ & 10.6 \\
\hline 7 Post & 66 & 79 & 88 & $30 \mathrm{c}$ & $460 \mathrm{ab}$ & 11.0 \\
\hline 8 Post & 94 & 95 & 95 & $0 \mathrm{~d}$ & $50 \mathrm{c}$ & 11.3 \\
\hline 9 Post & 100 & 99 & 98 & $0 \mathrm{~d}$ & $0 \mathrm{~d}$ & 10.7 \\
\hline 10 Post & 100 & 100 & 100 & $0 \mathrm{~d}$ & $0 \mathrm{~d}$ & 11.1 \\
\hline 11 Pre + Post & 97 & 98 & 98 & $\begin{array}{ll}0 & \mathrm{~d}\end{array}$ & $20 \mathrm{~cd}$ & 10.8 \\
\hline LSD $(\mathrm{P}<0.05)$ & 6.8 & 4.2 & 8.6 & & & 1.22 \\
\hline
\end{tabular}

${ }^{1}$ See Table 2 for a detailed description of the treatments.

${ }^{2}$ In each column, data with letters in common are not significantly different $(\mathrm{P}<0.05)$.

In Trial 3 imazethapyr/imazapyr again gave excellent control of the weeds in combination with the adjuvant Hasten (Table 6). When used with the alternative adjuvant, Weedmaster CT Surfactant, the level of weed control attained was significantly less. The best control was achieved when imazethapyr/imazapyr was used early postemergence by itself rather than late post-emergence following another herbicide. Imazethapyr/imazapyr effectively controlled all the annual species present, creeping buttercup and seedling docks. It also gave excellent knockdown of the large dock plants that were regrowing from old rootstock but, by the end of the season many were again regrowing from the same rootstock.

TABLE 6: Control of weeds $(\%)$ in Trial 3.

\begin{tabular}{|c|c|c|c|c|c|c|}
\hline \multirow[b]{2}{*}{ Treatment $^{1}$} & \multicolumn{2}{|c|}{ Annual weeds } & \multirow{2}{*}{$\begin{array}{c}\text { Fathen } \\
3.3 .99\end{array}$} & \multirow{2}{*}{$\begin{array}{c}\text { Buttercup } \\
3.3 .99\end{array}$} & \multicolumn{2}{|c|}{ Docks } \\
\hline & 23.12 .98 & 3.3 .99 & & & 3.3 .99 & 10.5 .99 \\
\hline 1 untreated & 0 & 0 & 0 & 0 & 0 & 0 \\
\hline $2 \mathrm{EPO}$ & 96 & 93 & 100 & 100 & 93 & 95 \\
\hline 3 EPO & 98 & 90 & 100 & 100 & 90 & 95 \\
\hline 4 EPO & 99 & 95 & 100 & 100 & 95 & 96 \\
\hline 5 Pre + LPO & 79 & 100 & 100 & 100 & 100 & 88 \\
\hline 6 Pre + LPO & 55 & 56 & 100 & 100 & 56 & 71 \\
\hline 7 Pre + LPO & 64 & 56 & 100 & 100 & 56 & 84 \\
\hline 8 Pre + LPO & 63 & 74 & 100 & 100 & 74 & 84 \\
\hline 9 Pre + LPO & 62 & 65 & 98 & 95 & 65 & 69 \\
\hline 10 Pre + LPO & 60 & 63 & 99 & 98 & 63 & 80 \\
\hline LSD $(\mathrm{P}<0.05)$ & 7.7 & 15.0 & - & - & 15.0 & 8.9 \\
\hline
\end{tabular}

${ }^{1}$ See Table 3 for a detailed description of the treatments. 


\section{Crop tolerance}

In all three trials imazethapyr/imazapyr was well tolerated by the IT maize varieties used. The crop was inspected every few days after the application of the herbicides for signs of injury. No discolouration, leaf distortion or stunting was observed at any stage. The production of grain in both Trials 1 and 2 was similar in all the treated plots, with only untreated control yielding significantly less (Tables 4 and 5).

\section{DISCUSSION AND CONCLUSIONS}

Results of these trials show that imazethapyr/imazapyr herbicide mixture was very effective in controlling a variety of both monocotyledonous and dicotyledonous weeds in IT maize crops. Imazethapyr/imazapyr was more effective when applied early postemergence than late post-emergence. Hasten was the most effective of the adjuvants tested with this combination giving superior weed control. The IT maize crop and final grain yields were not affected by these herbicides.

As well as annual weeds there are many difficult to control perennial weeds in New Zealand maize crops (Rahman 1985). Imidazolinone herbicides have already been found effective for control of some perennial weeds (Rahman \& Sanders 1992; Winfield \& De Ath 1985) and are currently being evaluated for their efficacy against weeds such as couch (Elytrigia repens), Mercer grass (Paspalum distichum), bindweeds (Calystegia spp.) and oxalis (Oxalis spp.) in maize.

For best management practices, growers should have available to them a complete range of products so they can choose to control weeds with either pre- or post-emergence applications of herbicides. Annual weeds growing in maize do not start to compete with the crop for at least the first 3 weeks after emergence (James et al. 2000). Thus, the availability of a broad spectrum herbicide such as imazethapyr/imazapyr that can be used post-emergence allows growers more freedom in designing their weed management programmes to target specific weeds over a greater application window. This will lead to reduced herbicide use, less environmental impact and ultimately, more sustainable practices.

\section{REFERENCES}

Botterman, J.; Leemans, J. 1988: Engineering of herbicide resistance in plants. Biotech. and Engineering Rev. 6: 321 - 340.

James, T.K.; Rahman, A.; Mellsop, J.M. 1999: Soil persistence and movement studies with imazethapyr and imazapyr. Proc. 17th Asian-Pacific Weed Sci. Soc. Conf.: 513-518.

James, T.K.; Rahman, A.; Mellsop, J.M. 2000: Weed competition in maize crop under different timings for post-emergence weed control. N.Z. Plant Prot. 53: 269 - 272.

Owen, M.D.K. 1997: North American developments in herbicide tolerant crops. Brighton Crop Prot. Conf. - Weeds: 955-963.

Rahman, A. 1985: Weed control in maize in New Zealand. Chapter 8. In: Eagles, H.A.; Wratt, G.S. ed. Maize Management to Market. Agronomy Society of N.Z. - Special Publication No. 4. Pp. 37-45.

Rahman, A.; James T.K.; Sanders, P. 1993: Persistence and movement of imazapyr in different soil types. Proc. 46th N.Z. Plant Prot. Conf.: 115-119.

Rahman, A.; Sanders, P. 1992: Herbicides for control of two bindweed species (Calystegia silvatica and Convolvulus arvensis) in asparagus. Proc. 45th N.Z. Plant Prot. Conf.: $27-30$.

Shaner, D.L. 1991: Imidazolinone herbicides. Pesticide Outlook. 2 (4): 21-24.

Shaner, D.L. 1996: Herbicide-resistant crops: a new tool in herbicide-resistant weed management. Proc. 2nd Int. Weed Control Congress 2: 421-425.

Winfield, R.J.; De Ath, M.R. 1985: Performance of AC 252925 for control of wide range of weeds on railways and industrial sites in the UK. Proc. Brit. Crop Prot. Conf. - Weeds: $873-878$. 